\title{
A. Skreczko, Rodzina Bogiem silna, Białystok 2004, ss. 295
}

Uświadomienie celu i zadań - tak w życiu indywidualnym, jak i społecznym - domaga się poszukiwania charakterystycznych wyznaczników istnienia i działania osoby czy wspólnoty ludzkiej. Społecznością, która skupia w sobie cele i zadania zarówno jednostkowe, jak i wspólnotowe jest rodzina. Ona więc winna ciągle rozpoznawać zarówno stałe i niezmienne, jak też czasowe i sytuacyjne wyznaczniki swego istnienia. Uświadomienie ich oraz kierowanie się nimi w codziennym życiu stanowi fundamentalny normatyw życia rodzinnego. Tego rodzaju przekonanie znajduje swe uzasadnienie zarówno w historii, jak w świadomości ludzi nam współczesnych. Pomocą w rozpoznawaniu owych wyznaczników i celów życia rodzinnego byli i są ludzie pełniący szczególne funkcje i zadania w danym okresie dziejów i w konkretnej społeczności. Ich poglądy na wiele lat ukierunkowują myślenie innych, a postawy życiowe stają się wzorcem do naśladowania. W odpowiednich sytuacjach życiowych wracamy do nich, starając się odnaleźć wskazania do czekających nas zadań i decyzji.

Tego rodzaju problematykę podejmuje ks. Adam Skreczko w swej książce zatytułowanej Rodzina Bogiem silna. Autor jest pedagogiem oraz dr. hab. teologii pastoralnej, pracownikiem naukowo-dydaktycznym Uniwersytetu Kardynała Stefana Wyszyńskiego, Instytutu Nauk o Rodzinie w Łomiankach. Przygotowanie merytoryczne Autora wyznacza sposób ujęcia podjętego w tej książce zagadnienia. Jest to analiza natury teologiczno-pastoralnej, z podkreśleniem wymiaru duchowo-moralnego oraz pedagogicznym wskazaniami praktycznymi. Tytuł książki stanowią słowa kard. S. Wyszyńskiego, który często podkreślał, że „rodzina Bogiem silna”, a „naród silny rodziną”. Wyjaśniając tytuł, ks. A. Skreczko stwierdza: „By rodzina mogła nadać właściwy poziom i godność Życiu swoich członków oraz narodowi, sama musi korzystać z pierwszego źródła, którym jest Bóg. Ma być silna w Bogu, umocniona przez Boga w swej trwałości i w swym działaniu, od Boga czerpiąca swą moc wewnętrzną" (s. 7). Należy też pamiętać, że te idee stanowiły podstawę programu duszpasterskiego, jakim była Wielka Nowenna przygotowująca Kościół w naszej Ojczyźnie do obchodów tysiąclecia Chrztu Polski w 1966 roku. Problemy rodziny tamtych czasów nie tylko nie straciły na aktualności, ale jeszcze bardziej dzisiaj domagają się pogłębionej refleksji i poszukiwań ich rozwiązywania. 
Autor omawianej książki swoje analizy podjętych tu problemów zawarł w trzech kolejnych rozdziałach. W pierwszym, zatytułowanym „Rodzina podstawową droga Kościoła”, ukazuje panoramę podstawowych prawd i wymogów odnoszących się do natury i funkcjonowania rodziny, zwłaszcza w warunkach polskich. Uzasadniając fakt i wymóg, że rodzina jest w centrum pastoralnej działalności Kościoła, ks. A. Skreczko pisze: „Decyduje o tym naturalna i nadprzyrodzona doniosłość posłannictwa rodziny, jak również liczba wciąż pojawiających się zagrożeń utrudniających, czy wprost uniemożliwiających prawidłowy rozwój życia rodzinnego" (s. 11). Rozwijając tak pojmowany problem, Autor najpierw charakteryzuje troskę polskiego Kościoła o małżeństwo i rodzinę, eksponując postawę Prymasa Tysiąclecia wobec polskiej rodziny. Ogląd tej rzeczywistość polskiej rodziny został poszerzony o wskazania i wymogi watykańskiej Karty Praw Rodziny, z podkreśleniem znaczenia tego dokumentu we współczesnej teologii i praktyce duszpasterskiej. Na płaszczyźnie praktyki duszpasterskiej w Polsce rozumienie rodziny jako „drogi Kościoła” ujawnia się - zdaniem ks. A. Skreczko - w dwóch nurtach działania: przygotowania kapłanów do duszpasterstwa rodzin oraz w uczynieniu z rodziny fundamentalnego celu nowej ewangelizacji.

Rozdział drugi poświęcony jest zadaniom wychowawczym rodziny. Jego tytuł - Rodzina środowiskiem dorastania - wskazuje na szczególną funkcję rodziny w formowaniu dojrzałości człowieka. Analizując to zagadnienie, Autor przywołuje nauczanie pasterzy polskiego Kościoła w okresie Wielkiej Nowenny. Na kanwie tej bazy źródłowej podejmuje takie problemy, jak: rodzina miejscem wychowania, rodzicielstwo oraz ojcostwo według kard. S. Wyszyńskiego. Ks. A. Skreczko podkreśla, że „fenomen i znaczenie Wielkiej Nowenny zależały w dużym stopniu od jej trafności merytorycznej. Nauczano wówczas, że rodzina jest ostoją państwa, stąd i państwo winno być całą swą istotą skierowane ku dobru rodziny. "Rodzina Bogiem silna" musi być nastawiona na dobro dzieci, i to jest jej przyszłością. [...] Podkreślana wówczas prawda, że rodzina jest podstawowym środowiskiem wychowania nie przestała być aktualna i w naszych czasach" (s. 97).

Rodzina darem $i$ zdaniem - to tytuł trzeciego rozdziału omawianej książki. Podejmowane tu zagadnienia oraz sposób ich interpretacji koncentrują się wokół charakteru normatywnego natury i funkcjonowania rodziny. Ten wymiar wspólnoty rodzinnej wynika - zdaniem ks. A. Skreczko - ze szczególnej natury owej wspólnoty. Należy bowiem pamiętać, że „wspólnota tworzona przez dwoje ludzi nie jest czymś statycznym. Wpisana jest w nią pewna dynamika, która stwarza pole zagrożeń, jest też źródłem konfliktów oraz kryzysów" (s. 155). Analizując tak sformułowany problem, Autor ukazuje najpierw najgroźniejsze i najbardziej rozpowszechnione dziś zagrożenia małżeństwa, wskazując na św. Józefa i Maryję jako wzór świętości życia małżeńskiego. Następnie podkreśla pewne uwarunkowania i sposoby zaradzania trudnościom życia małżeńsko-rodzinnego. Są to: przygotowanie do życia w rodzinie, problemy edukacyjne w życiu rodziny, w tym służebną funkcję szkoły, 
świadomość wychowawcza rodziców, podeszły wiek w aspekcie wychowawczym, rodzina miejscem kształtowania kultury chrześcijańskiej oraz kultura życia rodzinnego. Szczególną świadomość owych powinności życia rodzinnego w przeciwstawianiu się współczesnym zagrożeniom posiada rodzina katolicka. Ten normatyw trafnie dostrzega cytowany przez A. Skreczko L. Dyczewski. Podkreśla on, że „katolickie rodziny muszą tworzyć kolejną nową kulturę chrześcijańską. Winna ona być kulturą alternatywną w stosunku do dzisiejszej kultury dominującej. Przy czym katolicka kultura alternatywna to coś więcej niż tylko krytyka cech kultury ogólnie upowszechniającej się, to coś więcej niż tylko propozycja ideologiczna, czyli zbiór powiązanych z sobą oraz uzasadnionych wartości, idei i norm. Katolicka kultura alternatywna to całościowy styl życia" (s. 252).

W ostatnim rozdziale swej książki ks. A. Skreczko zamieszcza wybrane dokumenty Kościoła w Polsce okresu Wielkiej Nowenny. Są to: pisma Prymasa Polski ks. kard. Stefana Wyszyńskiego, nauczanie Episkopatu Polski oraz pojedynczych polskich biskupów. Zawarte tu fragmenty kościelnego nauczania pasterzy polskiego Kościoła są dobrą ilustracją źródłową podjętych w omawianej książce problemów. Czytelnikowi umożliwiają też sięgnięcie do oryginalnych wypowiedzi na tematy zawarte w tej książce. Ukazują one klimat życia polskiego Kościoła i rodzin tamtych czasów, dając też możliwość wykorzystania ich w różnych formach pracy teologiczno-pastoralnej.

Próbując wskazać szczególne walory i znaczenie książki ks. A. Skreczko, należy podkreślić aktualność podjętych tu zagadnień. Autor, podejmując analizę kościelnych dokumentów konkretnego polskiego Kościoła, w tym także problemy ówczesnych rodzin, w sposób profesjonalny od strony teologii rodziny oraz trafnie ze względów pastoralno-pedagogicznych ukazuje podstawowe problemy życia rodzinnego. Drugim bardzo ważnym atutem tej książki jest jej wiarygodność źródłowo-eklezjalna, co we współczesnym zamieszaniu poglądów i postaw życia religijno-moralnego należy szczególnie podkreślić. Te aktualne dziś problemy rodziny, zakotwiczone w wiarygodnych źródłach teologiczno-eklezjalnych, ks. A. Skreczko ukazuje w sposób analitycznie poprawny, merytorycznie pogłębiony, przystępnym językiem, ze wskazaniem trafnych i „życiowych" wniosków i praktycznych zastosowań prowadzonych analiz. Z tych względów książka ta godna jest polecenia zarówno teologom, jak duszpasterzom i wszystkim zajmującym się pomocą rodzinie, ale też - a może przede wszystkim - tworzącym wspólnoty życia małżeńsko-rodzinnego.

Zaangażowanie czytelnika w lekturę tej interesującej książki rodzi też pewien niedosyt. Pierwsze wrażenie, jakie się narzuca można by określić mianem „szybkość edytorska”. Dostrzec tu można swoisty pośpiech w przygotowywaniu zawartych tekstów do druku, co objawia się np. brakiem choćby krótkich wprowadzeń do poszczególnych rozdziałów, które jeszcze lepiej pozwalałyby czytelnikowi wstępnie zorientować się w zwartości merytorycznej danej części książki. Tego rodzaju wprowadzenia „domaga się” zwłaszcza ostatni rozdział książki, zawierający teksty nauczania pasterskiego polskich 
biskupów. Czytelnik współczesny, zwłaszcza wiekowo młody, z pewnością byłby wdzięczny za choćby krótkie wprowadzenie w klimat tamtych czasów i orientację co do postaci Autorów prezentowanego nauczania pasterskiego. Dobrze by też było, gdyby Autor zatroszczył się o zamieszczenie choćby wybranej literatury przedmiotu, również z myślą o czytelniku chcącym pogłębić sobie treści spotykane w tej książce. Wprawdzie książka - jeżeli dobrze odczytałem zamiar Autora - ma charakter bardziej „praktyczny” niż „teoretyczny", co usprawiedliwia wskazane tu braki, ale owe uzupełnienia z pewnością powiększyłyby jej wartość.

Lektura książki Rodzina Bogiem silna skłania do wyrażenia radości z faktu jej ukazania się, a Autorowi wdzięczności za podjęcie tej problematyki i kompetentne jej przedstawienie. Sam tytuł, podkreślający źródło siły wspólnoty rodzinnej, jakim jest Bóg jest trafny i znamienny w naszych czasach zamętu wokół pojmowania rodziny, jej egzystencjalnego zakotwiczenia oraz sensu i celu istnienia. Rozwijając tytułowy problem, Autor konsekwentnie wykazał, w czym wyraża się owa Boża sita rodziny, jak ją rozpoznać i osiągać w codziennym życiu tej wspólnoty. Te i inne walory omawianej książki pozwalają polecić ją dosłownie każdemu, gdyż każdy z nas w rodzinie ma swój początek, a zdecydowana większość społeczności ludzkiej w małżeństwie i rodzinie realizuje swe życiowe powołanie. W realizacji zaś zadania, aby była ona Bogiem silna w dużym stopniu pomoże nam lektura książki ks. A. Skreczko.

Ks. Józef Zabielski 